\title{
IMPROVEMENT OF LOCAL SUBGRADE SOIL FOR ROAD CONSTUCTION BY THE USE OF COCONUT COIR FIBER
}

\author{
R.R Singh ${ }^{1}$, Er. Shelly Mittal ${ }^{2}$ \\ ${ }^{I}$ Professor, Civil Engineering Department, Punjab Engineering College, Chandigarh, India \\ ${ }^{2}$ M.E student, Civil Engineering Department, Punjab Engineering College, Chandigarh, India
}

\begin{abstract}
Use of waste material and natural fiber for improving soil property is advantageous because they are cheap, locally available and eco-friendly. In this study, the stabilizing effect of Natural fiber (coconut coir) on soil properties has been studied. Over the last decade the use of waste material and fiber has recorded a tremendous increase. Keeping this in view an experimental study is conducted on locally available i.e. clayey soil mixed with varying percentage of coir fiber. Soil samples for unconfined compression strength (UCS) and California bearing ratio (CBR) tests are prepared at its maximum dry density corresponding to its optimum moisture content in the CBR mould without and with coir fiber. The percentage of coir fiber by dry weight of soil is taken as $0.25 \%, 0.50 \%, 0.75 \%$ and $1 \%$ and corresponding to each coir fiber content unsoaked and soaked CBR and UCS tests are conducted in the laboratory. Tests result indicates that both unsoaked and soaked CBR value of soil increases with the increase in fiber content. Soaked CBR value increases from $4.75 \%$ to $9.22 \%$ and unsoaked CBR value increases from $8.72 \%$ to $13.55 \%$ of soil mixed with $1 \%$ coir fiber. UCS of the soil increases from $2.75 \mathrm{~kg} / \mathrm{cm}^{2}$ to $6.33 \mathrm{~kg} / \mathrm{cm}^{2}$ upon addition of $1 \%$ randomly distributed coconut fiber. Adding of coconut coir fiber results in less thickness of pavement due to increase in CBR of mix and reduce the cost of construction and hence economy of the construction of highway will be achieved. This is because of composite effect of natural fiber changes the brittle behavior of the soil to ductile behavior.
\end{abstract}

Keywords: Soil, Coconut coir fiber, UCS and CBR values.

\section{INTRODUCTION}

Keeping in mind the large geographical area of India $(3,287,240 \mathrm{sq} . \mathrm{km})$ and population of India (125 million apporx.) the vast network of road is required. Soil being the cheapest and readily available construction material, has been Popular with the civil Engineers, even though it being poor properties. It has been the constant endeavor of research workers to put forth innovative ideas to improve its mechanical properties to suit the requirements of engineering students. The construction of road imposes a heavy pressure on limited resources like suitable earth, stone aggregates binders etc. For sustainable development use of locally available materials, waste material should be encouraged in order to save the natural resources for future generation. There are many types of waste material found in India like coal ash, stone quarry, plastics, recycled aggregate, geosynthetic materials and polythene bags etc but coconut coir fiber is used in this research paper. In future many roads and highways will be constructed near the Chandigarh. Coconut coir fiber may be utilized in these highways projects.

Coir or coconut fiber belongs to the group of hard structural fibers. It is an important commercial product obtained from the husk of coconut. The coir fiber is elastic enough to twist without breaking and it holds a curl as though permanently waved. Shorter mattress fibers are separated from the long bristle fibers which are in turn a waste in the coir fiber industry. So this coir fiber waste can be used in stabilization of soil and thus it can be effectively disposed off. The inclusion of fibers had a significant influence on the engineering behavior of soil-coir mixtures. The addition of randomly distributed polypropylene fibers resulted in substantially reducing the consolidation settlement of the clay soil. Length of fibers has an insignificant effect on this soil characteristic, whereas fiber contents proved more influential and effective. Addition of fiber resulted in decrease in plasticity and increase in hydraulic conductivity. As a result there has been a growing interest in soil/fiber reinforcement. The work has been done on strength deformation behavior of fiber reinforced soil and it has been established beyond doubt that addition of fiber in soil improves the overall engineering performance of soil. Fiber mixed with soil has been used in many countries in the recent past and further research is in progress for many hidden aspects of it. Fiber mixed with soil is effective in all types of soils (i.e. sand, silt and clay). The main advantage of coir material is this it is locally available and is very cheap. This is biodegradable and hence do not create disposal problem in environment. This research presents the influence of coir fiber on the UCS and CBR value of soil from Industrial area, panchkula, India. The number of unsoaked and soaked CBR value and UCS tests have been conducted on soil and soil mixed with varying amount of coir fiber $(0.25,0.50,0.75$, and $1.0 \%)$. The UCS and CBR values of soil-coir have been compared with that of unmixed soil 


\section{LITERATURE REVIEW}

Many Studies have also shown that durability of natural fiber can be improved using coating of fiber with Phenol and Bitumen. Many studies have been conducted relating to the behaviour of soil reinforced with randomly distributed fiber. Gray and Ohashi (1983)[1] conducted a series of direct shear tests on dry sand reinforced with different synthetic, natural and metallic fiber to evaluate the effects of parameters such as fiber orientation, fiber content, fiber area ratios, and fiber stiffness on contribution to shear strength. Based on the test results they concluded that an increase in shear strength is directly proportional to the fiber area ratios and shear strength envelopes for fiber-reinforced sand clearly shows the existence of a threshold confining stress below which the fiber tries to slip or pull out. Various types of randomly distributed elements such as polymeric mesh elements, synthetic fiber (Gray and Al Refeai 1986[2], Mahar and Gray 1990[11], Ranjan et. Al, 1996[3], Charan 1995[4], Michalowski and Cermak, 2003[5], Gosavi et al., 2004[6], Rao et al., 2006[7], Chanda et al. 2008 and Singh 2011[8] metallic fiber (Fatani et al.1999)[9] and discontinuous multioriented polypropylene elements (Lawton et.al, 1993)[10] have been used to reinforce soil and it has been shown that the addition of randomly distributed elements to soils contributes to the increase in strength and stiffness. Lekha (2004) and Vishnudas et al. (2006) have presented a few case studies of construction and performance monitoring of coir geotextile reinforced bunds and suggested that the use of coir is a cost effective ecohydrological measure compared to stone-pitching and other stabilization measures used in the protection of slopes and bunds in rural areas.

\section{EXPERIMENTAL PROGRAM}

The following tests are conducted for soil and coir. Determination of Grain sieve analysis, Proctor test, U.C.S. test and C.B.R. test. All test are carried as per IS 2720.

\section{Mix Proportion Used}

Soil with $0.25 \%, 0.50 \%, 0.75 \%, 1.0 \%$ Coir by weight.

\section{MATERIALS AND TEST PROCEDURE}

\subsection{Soil}

The soil used in this investigation is local soil of industrial area, Panchkula. According to Indian Standard of soil classification (IS 1498:1970) the soil is classified as clayey soil (CL).
The properties of soil are as under:-

Table-1: Properties of Soil

\begin{tabular}{|c|c|c|}
\hline Sr.No & Properties of soil & Laboratory value \\
\hline 1. & $\begin{array}{l}\text { Atterberg Limits (\%) } \\
\text { Liquid Limit } \\
\text { Plastic Limit } \\
\text { Plasticity Index }\end{array}$ & $\begin{array}{l}22.4 \\
15.6 \\
6.8\end{array}$ \\
\hline 2. & $\begin{array}{l}\text { Indian Standard } \\
\text { Classification }\end{array}$ & $\begin{array}{l}\text { CL(clay of Low } \\
\text { Compressibility) }\end{array}$ \\
\hline 3. & $\begin{array}{l}\text { Proctor Test Results } \\
\text { Maximum Dry } \\
\text { Density } \\
\text { Optimum Moisture } \\
\text { Content(OMC) in \% }\end{array}$ & $\begin{array}{l}2.04 \\
11.8\end{array}$ \\
\hline
\end{tabular}

\subsection{Coir}

The coir is purchased from market. It is the fibrous portion of the coconut extracted mainly from the green nut. Coir extracted consists of rotting the husk in water and removing the organic material binding the fiber. Diameter is $0.5 \mathrm{~mm}$. The coir is cut into pieces of $3 \mathrm{~cm}$ to $5 \mathrm{~cm}$, as those percentage remains $0.25,0.50,0.75,1 \%$.

\subsection{Test Procedure}

For unconfined compression tests, cylindrical specimens are prepared at the standard Proctor maximum dry unit weight and optimum moisture content of the composite. A $38 \mathrm{~mm}$ inner diameter and $76 \mathrm{~mm}$ long mould with additional detachable collars at both ends is used. To ensure uniform compaction, the entire required quantity of the moist soil coir with and without fiber is placed inside the mouldcollars assembly and compressed in the automatic compaction machine till the specimen reached the dimensions of the mould. The compacted specimen is extruded from the mould using a hydraulic jack. Three specimens are prepared for each combination and tested for UCS as per IS 2720, part 10.

CBR test specimens are prepared by applying modified compaction efforts to unmixed and mixed clayey soil at their respective optimum moisture content (OMC) obtained in the compaction tests. Two types of tests are run, unsoaked and soaked. A surcharge mass of $4.5 \mathrm{~kg}$ is placed on the surface of the compacted specimens and then the samples are soaked in water for a period of four days. After four days of soil were determined corresponding to plunger penetration of 2.5 and $5 \mathrm{~mm}$ per the standard procedure laid down soaking, the mould assembly was taken out from water and 
the top surface of water was left exposed to air for half an hour. The CBR mould along with soaked soil sample was brought to a motorized loading frame for testing. The CBR values of the test samples of unreinforced and reinforced in IS:2720, Part 16

\section{RESULTS AND DISCUSSIONS}

In these results soil is added with different ratios of coconut coir. The main parameters that are studied include unconfined compression strength and C.B.R. The numbers of curves are placed from the test results of U.C.S. and C.B.R. tests are performed on the soil and soil mix with different percentage of coir fiber. Coir increases the U.C.S and C.B.R values in this investigation. The experimental results are carried out in the following laboratory works.

\subsection{Unconfined Compression Test}

Table -2: Unconfined Compression Test for Different Coir Mixes

\begin{tabular}{|l|l|l|}
\hline S.No. & $\begin{array}{l}\text { Soil Mix- Soil: } \\
\text { Coir }\end{array}$ & $\begin{array}{l}\text { Unconfined } \\
\text { Compressive } \\
\text { Strength } \\
\left(\mathbf{k g} / \mathrm{cm}^{2}\right)\end{array}$ \\
\hline 1 & $100: 0$ & 2.75 \\
\hline 2 & $99.75: 0.25$ & 2.9 \\
\hline 3 & $99.50: 0.50$ & 4.52 \\
\hline 4 & $99.25: 0.75$ & 5.31 \\
\hline 5 & $99: 1.0$ & 6.33 \\
\hline
\end{tabular}

There is considerable improvement in compressive strength in case of all the soils on account of treatment with coconut coir fiber. The values of unconfined compressive strength are increased as more percentage of soil is replaced with coconut coir. From Table 2 the range of unconfined compressive strength of soil varies from $2.75 \mathrm{~kg} / \mathrm{cm}^{2}$ to 6.33 $\mathrm{kg} / \mathrm{cm}^{2}$ (treated with $1.0 \%$ coir). It is noted that the compressive strength of soil increases when treated with coir (fiber) up to $1 \%$. The increase may be due to the increase in shear parameters. \%. It was difficult to prepare the identical samples (at constant dry density) of reinforced soil beyond $1 \%$ of fiber content and hence in the present study the maximum coir fiber content was considered to be $1 \%$ by dry weight of soil. The variation of U.C.S with varying percentage of coir is depicted in figure1.

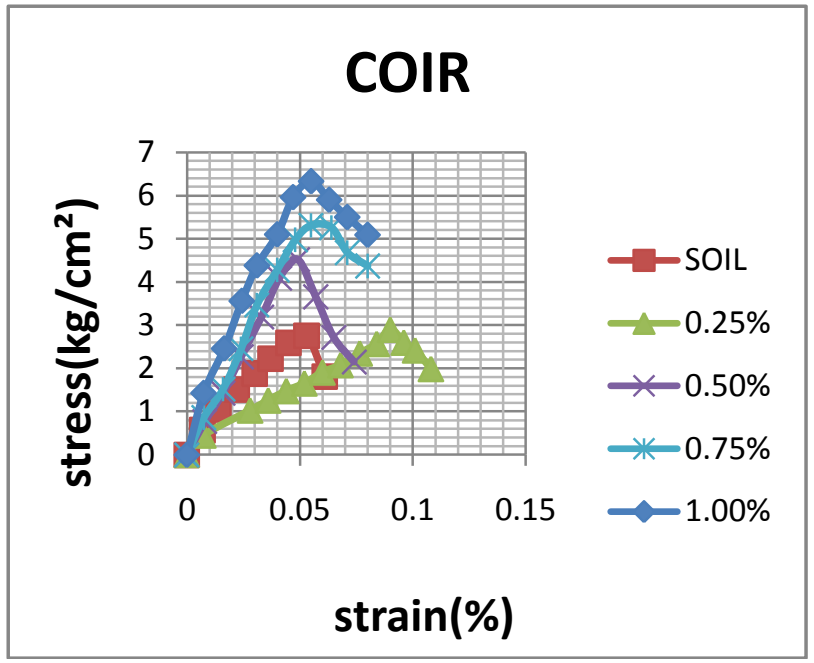

Fig. 1: Graph of Unconfined Compression Test for Different Coir mixes

\subsection{California Bearing Ratio Test}

Table- 3: Soaked and unsoaked CBR value of soil coir mix

\begin{tabular}{|l|l|l|l|l|}
\hline $\begin{array}{l}\text { Sample } \\
\text { Soil : Coir }\end{array}$ & $\begin{array}{l}\text { C.B.R } \\
\text { Unsoaked } \\
(\%)\end{array}$ & $\begin{array}{l}(\%) \\
\text { Increase }\end{array}$ & $\begin{array}{l}\text { C.B.R. } \\
\text { Soaked } \\
(\%)\end{array}$ & $\begin{array}{l}(\%) \\
\text { Increase }\end{array}$ \\
\hline $100: 00$ & 8.72 & & 4.75 & \\
\hline $99.75: 0.25$ & 9.83 & 13 & 6.82 & 43 \\
\hline $99.50: 0.50$ & 10.94 & 25 & 7.77 & 63 \\
\hline $99.25: 0.75$ & 12.37 & 42 & 8.24 & 73 \\
\hline $99.00: 1.00$ & 13.55 & 55 & 9.22 & 94 \\
\hline
\end{tabular}

The unsoaked and soaked CBR values are determined in the laboratory for soil mixed with varying percentage of coir fiber content are shown in Table 3 respectively. It is clear from the tests results of Table 3 that both unsoaked and soaked CBR value of soil increases as the coir fiber content increases. The maximum unsoaked CBR value of mixed soil is $13.55 \%$ that of plain soil at a coir fiber content of $1 \%$. In case of soaked test the maximum CBR value of mixed soil is $9.22 \%$ that of plain soil at a coir fiber content of $1 \%$.This is due to reason that randomly distributed fiber incorporated into soil mass improves its load deformation behavior by interacting with the soil particles mechanically through surface friction and also by interlocking. Further, addition of coir fiber makes the soil a composite material whose strength and stiffness is greater than that of unreinforced soil. The strength and stiffness of reinforced soil increases with the increase in fiber content and may be due to this reason also the CBR value of reinforced soil was observed to be greater than that of unreinforced soil. The optimum fiber content corresponding to maximum improvement in CBR value is found to be $1 \%$. It was difficult to prepare the identical samples (at constant dry density) of reinforced soil beyond $1 \%$ of fiber content and hence in the present study the maximum coir fiber content was considered to be $1 \%$ by dry weight of soil. Similar trend was observed by H.P Singh (2013). The variation of unsoaked and soaked C.B.R. with 
varying percentage of coir is depicted in figure $2 \& 3$.

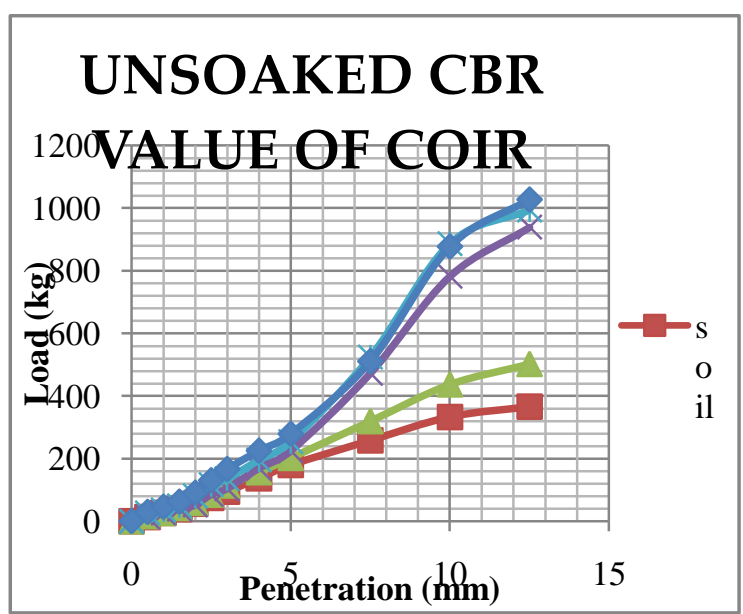

Fig -2: Graph of Unsoaked C.B.R. Test for Different Coir Mixes

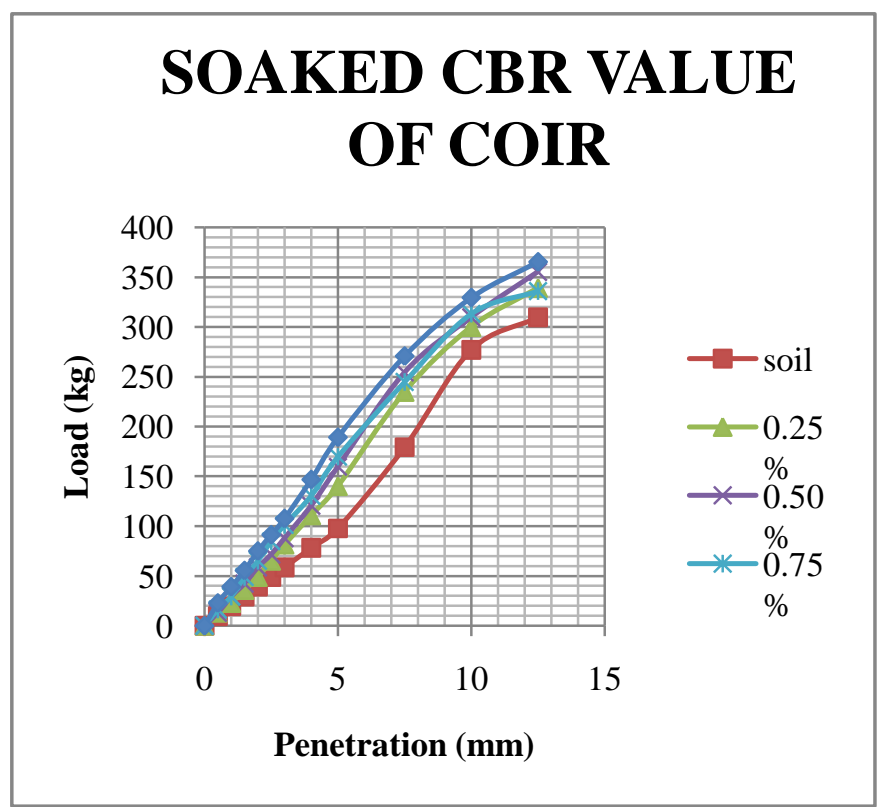

Fig -3: Graph of Soaked C.B.R. Test for Different Coir Mixes

Based upon the study it is concluded that proportion of $1 \%$ coir fiber in a soil is the best combination of materials having maximum soaked CBR value. Hence this proportion may be used in road pavement and embankments.

\section{DESIGN FOR PAVEMENT THICKNESS}

After doing testing on various samples, with the help of CBR design chart recommended by Indian Road Congress IRC: SP: 20: 2002 the total thickness is found out to cover the sub grade for all samples.

It is assumed that there are 400 no. of commercial vehicles per day. So, curve D is used for obtaining thickness over subgrade. CBR curves for flexible pavements design (IRC: SP: 20-2002).
Table - 4: Thickness of pavement above sub grade from IRC: SP: 20-2002

\begin{tabular}{|l|l|l|l|}
\hline S.NO. & $\begin{array}{l}\% \quad \text { OF } \\
\text { COIR }\end{array}$ & $\begin{array}{l}\text { SOAKED } \\
\text { CBR } \\
\text { VALUE }\end{array}$ & $\begin{array}{l}\text { THICKNESS OF } \\
\text { FEXIBLE } \\
\text { PAVEMENT } \\
(\mathrm{mm})\end{array}$ \\
\hline 1 & 0 & 4.75 & 390 \\
\hline 2 & 0.25 & 6.82 & 320 \\
\hline 3 & 0.50 & 7.77 & 290 \\
\hline 4 & 0.75 & 8.24 & 280 \\
\hline $\mathbf{5}$ & $\mathbf{1 . 0}$ & $\mathbf{9 . 2 2}$ & $\mathbf{2 6 0}$ \\
\hline
\end{tabular}

From Table 4 this shows that the thickness of flexible pavements of different percentages of CBR values. The soil added with $1 \%$ coir give the best results of CBR, so the thickness of flexible pavement of this result is $260 \mathrm{~mm}$. It is the minimum thickness as compare to other samples. The cost of pavement is reducing to add this waste material.

\section{CONCLUSIONS}

The present study has shown quite encouraging results and following important conclusions can be drawn from the study:

- Coir fiber is a waste material which could be utilized in a sub base for flexible and rigid pavements.

- The OMC of soil-coir mix increases with increasing the percentage of coir fiber.

- $\quad$ CBR and UCS values of soil-coir fiber mix increases with increasing percentage of fiber.

- Maximum improvement in U.C.S. and C.B.R. values are observed when $1 \%$ of coir is mixed with the soil.

- It is concluded that proportion of $1 \%$ coir fiber in a soil is optimum percentage of materials having maximum soaked CBR value. Hence, this proportion may be economically used in road pavement and embankments.

\section{REFERENCES}

[1] Gray, D.H., and Ohashi, H. (1983), "Mechanics of fiber reinforcing in sand, Journal of Geotechnical Engineering",ASCE 112(8): 335-353.

[2] Gray, D.H., and Al-Refeai, T.(1986), "Behaviour of fabric- versus fiber-reinforced sand, Journal of Geotechnical Engineering," ASCE, 112(8): 804-820.

[3] Maher, M.H. and Gray, D.H. (1990).” Static response of sands

[4] Charan H.D. (1995), "Probabilistic analysis of randomly distributed fiber soil." Ph.D. Thesis, Dept. of Civil Egg. I.I.T Roorkee, Roorkee, India

[5] Michalowski, R.L. \& Cerma'k, J. (2002). "Strength anisotropy of fiber reinforced sand", Compute. Geotech. 29, No. 4,279-299.

[6] Gosavi, M., Patel, K.A, Mittal, S. and Saran, S (2004). "Improvements of properties of black cotton soil subgrade through synthetic reinforcement", Journal of Institution of reinforced with randomly 
distributed fibers". Journal of Geotechnical Engineering, ASCE. 716 (11), 1661-1677

[7] Ranjan, G., Vasan, R.M. and Charan, H.D. (1996)," Probabilistic analysis of randomly distributed fiberreinforced soil", Journal of Geotechnical Engineering, ASCE, 122(6): 419-426

[8] Engineers (India), 84,257-262.

[9] Rao, A.S. Rao, K.V.N., Sabetha, G. and SurestL K. (2006)." Load deformation behavior of fiberreinforced gravel beds overlying soft clay". A National Conference on Corrective Engineering Practices in Troublesome Soils (CONCEPTS), Kakinad4 8-9 luly, 2006, 187 -190

[10] Singh, H.P., Sharma, A., and Chanda, N.(2011), "Study Of Strength Characteristics of Coir Reinforced Soil", International Conference on Advances in Material and Techniques for Infrastructure Development held at NIT Calicut Kerala, India. Paper No.: G002, 28-30 September.

[11] Lawton E.C., Khire, M.V. and Fox, N.S. (1993). "Reinforcement of soils by multioriented geosynthetic", inclusion. Journal of Geotechnical Engineering ASCE, 119(2),257-275

[12] Fatani, N.M., Bauer, G.H., and Al-Joulani, N.(1999) . "Reinforcing soil with aligned and randomly oriented metallic", Journal of ASTM Geotech Testing (1), pp 78-87.

[13] SP 20 (1997): "Manual on route location design construction maintenance of rural roads (other districts roads and village roads)" Publication, Indian Road Congress, New Delhi.

[14] IS: 2720, Part XVI, 1965. Laboratory determination of CBR, Bureau of Indian Standards; New Delhi.

[15] Singh, H.P., (2013), Effects of Coir Fiber on CBR Value of Itnagar Soil, International Journal of current and Engineering and Technology, ISSN 2277 - 4106.

[16] IS: 2720, Part X, 1992, Laboratory determination of UCS, Bureau of Indian Standards; New Delhi 